\title{
Research Article \\ Fabrication of Photomagnetic Carbon Surfaces via Redox Assembly
}

\author{
Y.-L. Song and C. M. Wang \\ Department of Chemistry, National Taiwan Normal University, Taipei 116, Taiwan \\ Correspondence should be addressed to C. M. Wang; checmw@ntnu.edu.tw
}

Received 2 December 2016; Accepted 18 January 2017; Published 9 February 2017

Academic Editor: Feifei Cao

Copyright ( 2017 Y.-L. Song and C. M. Wang. This is an open access article distributed under the Creative Commons Attribution License, which permits unrestricted use, distribution, and reproduction in any medium, provided the original work is properly cited.

\begin{abstract}
3-Aminophenylboronic acid (APBA) and the complex $\mathrm{Ru}(\mathrm{bpy})_{2}(\text { phendione })^{2+}\left(\mathrm{bpy}=2,2^{\prime}\right.$-bipyridine, phendione $=1,10$ phenanthroline-5,6-dione) were found to be useful building blocks for preparing photomagnetic carbon surfaces. Scanning tunneling microscopy (STM) showed that when APBA was diazotized in acidic sodium nitrite solutions and cathodically reduced with highly ordered pyrolytic graphite (HOPG) electrodes, nanoscale films formed on the electrodes. The resulting HOPG had strong

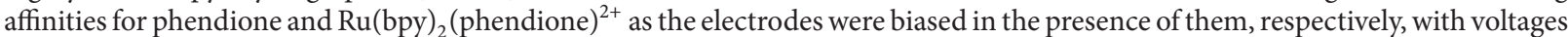
more negative than the cathodic peak potentials for phendione/phendiol and $\mathrm{Ru}(\mathrm{bpy})_{2}(\text { phendione })^{2+} / \mathrm{Ru}(\mathrm{bpy})_{2}(\mathrm{phendiol})^{2+}$ (phendiol = 1,10-phenanthroline-5,6-diol). However, if APBA was excluded, the affinities did not exist. Boronate ester formation featured prominently in these intermolecular interactions. The average increments in the HOPG surface roughness contributed by $\mathrm{APBA}$ and $\mathrm{Ru}(\mathrm{bpy})_{2}$ (phendione $)^{2+}$ were roughly $1: 2$, suggesting that the reaction stoichiometry between APBA and $\mathrm{Ru}(\mathrm{bpy})_{2}$ (phendione $)^{2+}$ be $1: 1$. Ru(bpy $)_{2}$ (phendione $)^{2+}$ could also be grafted to carbon nanotubes (CNTs) under conditions similar to those for the HOPG using ascorbate as sacrificial donor. The resulting CNTs and HOPG exhibited photomagnetism when exposed to the $473 \mathrm{~nm}$ light. The ruthenium complex was shown to be a room-temperature photomagnetism precursor, and APBA was shown to be an effective molecular bridge for the complex and carbon substrates.
\end{abstract}

\section{Introduction}

Photosensitive nanostructures have great potential for use in a wide variety of applications, including manipulating the physiology of DNA [1], enhancing light harvesting [2], and integrating photonanoelectronics [3] and photospintronics [4]. We have recently demonstrated that ordinary multiwalled carbon nanotubes (CNTs) develop photomagnetic and photoconductive characteristics after being modified with $\mathrm{Ru}(\text { bpy })_{2}\left(\text { phen- } \mathrm{NH}_{2}\right)^{2+}$ (phen- $\mathrm{NH}_{2}=5$-amino-1,10phenanthroline) through diazotization/denitrogenation processes [5]. Further research in this area has shown that many other ruthenium complexes, such as $\mathrm{Ru}(\mathrm{bpy})_{2}$ (phendione) $)^{2+}$, are also effective alternatives to $\mathrm{Ru}(\mathrm{bpy})_{2}\left(\text { phen- }-\mathrm{NH}_{2}\right)^{2+}$, and that boronic acids, including APBA, also can serve as surface adhesives [6].

Boronic acids, organic derivatives of boric acid, can form stable 5-membered cyclic dioxaborolanes or 6-membered dioxaborinanes with polyols [7]. Due to this unique property, APBA has recently been identified as a surface antenna and receptor for biochemically important substances, such as glucose and dopamine $[8,9]$. Phendione, on the other hand, is an effective redox mediator that is used in the electrochemical enzymatic detection of beta-hydroxybutyrate [10]. In fact, it is also a versatile chelating agent that can form homo- and

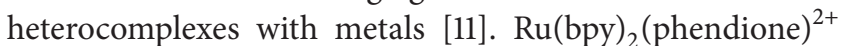
is one such example [12]. On cathodic reduction, phendione and $\mathrm{Ru}(\mathrm{bpy})_{2}$ (phendione) ${ }^{2+}$ yield phendiol and $\mathrm{Ru}(\mathrm{bpy})_{2}(\text { phendiol })^{2+}[13,14]$, which makes it electrocon-

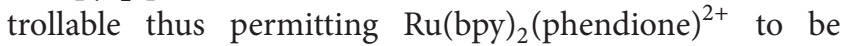
grafted onto carbon surfaces through APBA. The process for accomplishing this, which is shown in Scheme 1, is supported by the electrochemical impedance spectroscopic (EIS) and scanning tunneling microscopic (STM) characterizations. Herein, we report on the use of such a strategy to produce surface photomagnetism. 

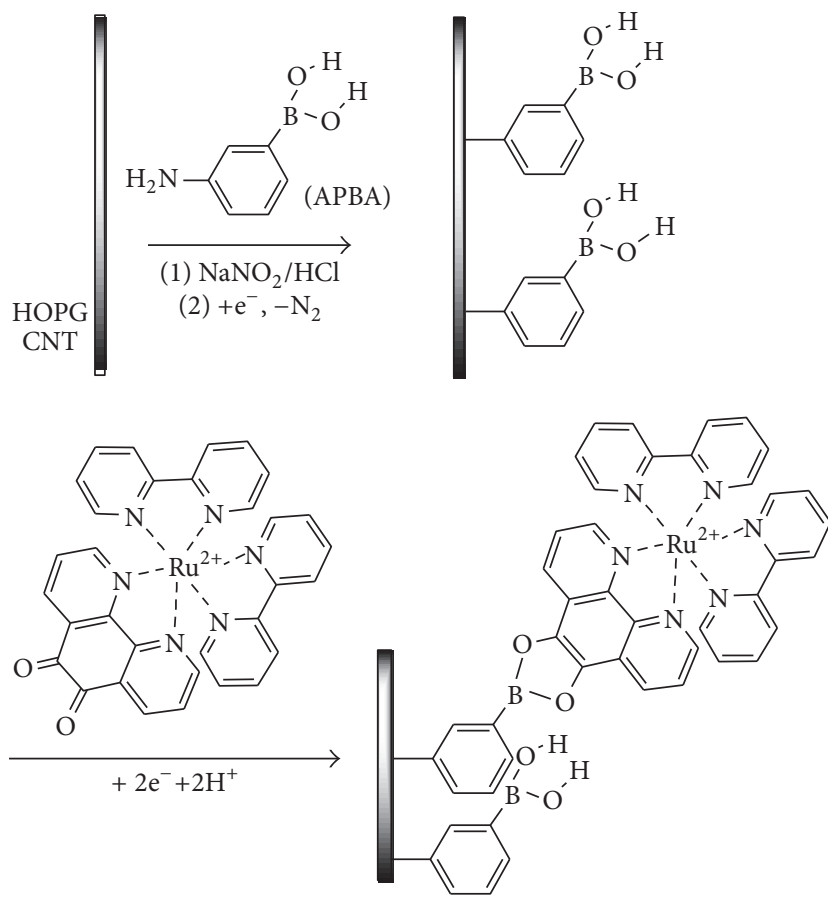

Scheme 1: Schematic illustration for the electrochemical attachment of APBA and $\mathrm{Ru}(\mathrm{bpy})_{2}$ (phendione $)^{2+}$ to carbon surface.

\section{Materials and Methods}

2.1. Chemicals. 3-Aminophenylboronic acid (APBA), tris $(2$, $2^{\prime}$-bipyridyl)dichlororuthenium(II) dihydrate $\left(\mathrm{Ru}(\mathrm{bpy})_{2} \mathrm{Cl}_{2}\right.$ $\cdot 2 \mathrm{H}_{2} \mathrm{O}$ ), 1,10-phenanthroline-5,6-dione (phendione), sodium nitrite $\left(\mathrm{NaNO}_{2}\right)$, sodium ascorbate, ammonium hexafluorophosphate $\left(\mathrm{NH}_{4} \mathrm{PF}_{6}\right)$, and highly ordered pyrolytic graphite sheets (HOPG) were purchased from Sigma-Aldrich (St. Louis, Missouri). All chemicals were used as received

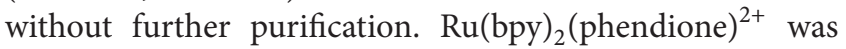
synthesized by reacting $\mathrm{Ru}(\mathrm{bpy})_{2} \mathrm{Cl}_{2} \cdot 2 \mathrm{H}_{2} \mathrm{O}$ with phendione according to a procedure described in the literature with minor modification [12]. Typically, $0.26 \mathrm{~g}$ of the former was allowed to react with $0.13 \mathrm{~g}$ of the later (molar ratio $1: 1.2$ ) in methanol $/ \mathrm{H}_{2} \mathrm{O}$ (volume ratio $1: 1$ ) under a reflux. The product was then subjected to anion exchange with $\mathrm{NH}_{4} \mathrm{PF}_{6}$ and recrystallization. The X-ray structure of the final product is provided in Figure S1 (in Supplementary Material available online at https://doi.org/10.1155/2017/6058216).

$\mathrm{Ru}(\mathrm{bpy})_{2}$ (phendione) ${ }^{2+}$-modified carbon tubes $(\mathrm{Ru} \mid$ APBA $\mid C N T)$ were prepared by reacting $40 \mathrm{mg}$ of multiwalled CNTs (purity > 99\%, length: 5-15 $\mu \mathrm{m}$, Golden Innovation Business Corp. Ltd., Taiwan) with APBA (0.01 M) and an equimolar amount of $\mathrm{NaNO}_{2}$ in $40 \mathrm{~mL} 0.1 \mathrm{M} \mathrm{HCl}$ at room temperature for $12 \mathrm{~h}$. During the course of the reaction, an equimolar amount of ascorbate was added gradually. The resulting CNTs (APBA|CNT) were redispersed in $40 \mathrm{~mL}$ of $1 \mathrm{mM} \mathrm{Ru}$ (bpy) ${ }_{2}$ (phendione) $\cdot 2 \mathrm{PF}_{6}$ with an excess of $\mathrm{NaBH}_{4}$ (in $\mathrm{CH}_{3} \mathrm{OH}$ ). After adjusting the $\mathrm{pH}$ to 3.5 , the solution was stirred for $12 \mathrm{~h}$ at room temperature. The products, after isolation, were stored under nitrogen until they were used.
2.2. Apparatus. A potentiostat (PAR 283, EG\&G) was used to record cyclic voltammograms (CVs). Unless otherwise specified, all electrochemical experiments were carried out under nitrogen in a one-compartment cell. The electrode potential reported in this work was against the saturated calomel electrode (SCE). For nonaqueous solutions, ferrocene ${ }^{0 /+}\left(E^{o \prime}\right.$ $=0.307 \mathrm{~V}$ versus SCE) was used as the internal standard. EIS experiments were carried out with an impedance analyzer (Autolab, Eco Chemie, Utrecht, The Netherlands). Ferricyanide $\left(\mathrm{Fe}(\mathrm{CN})_{6}{ }^{3-}\right)$ and ferrocyanide $\left(\mathrm{Fe}(\mathrm{CN})_{6}{ }^{4-}, 1 \mathrm{mM}\right.$ each in $0.1 \mathrm{M}$ potassium nitrate $\left(\mathrm{KNO}_{3}\right), E^{o \prime}=0.189 \mathrm{~V}$ versus SCE) served as the charge-transfer probe. The electrode potential was set at $0.189 \mathrm{~V}$ and superimposed with a sine wave $( \pm 10 \mathrm{mV})$ oscillating from $10^{5}$ to $10^{-4} \mathrm{~Hz}$ throughout all experiments. Data simulations were carried out based on a simplified Randles circuit (Figure S2) with the software provided by Autolab. Scanning electron microscopic (SEM) analyses were performed on a JEOL 6510 scanning electron microscope operating at $10 \mathrm{kV}$. An atomic force microscope (AFM, Nanoscope III E, Digital Instrument Corp.) with a $10 \mu \mathrm{m}$ scanner was employed for morphology analysis and surface scratching. For the latter, an area of $1 \mu \mathrm{m} \times 0.5 \mu \mathrm{m}$ was scratched under a force load of $0.5 \mu \mathrm{N}$ at a speed of $2 \mathrm{~Hz}$; each pit was scratched three times in succession. STM images were acquired with the same instrument in the constant current mode at ambient conditions and recorded at high impedances to reduce any damage to the target. Freshly cleaved HOPG sheets were employed to serve as the working electrode, and mechanically polished Pt/Ir tips were used as the scanning probe. The adsorption of APBA on HOPG was imaged in $1 \mathrm{mM}$ APBA with an equimolar amount of $\mathrm{NaNO}_{2}$ after the electrode was applied with voltages cycling between 0 and $-0.6 \mathrm{~V}$ versus SCE for one cycle at a scan rate of $50 \mathrm{mV} / \mathrm{s}$. For the further attachment with $\mathrm{Ru}(\mathrm{bpy})_{2}$ (phendione $)^{2+}$, the solution was replaced by $1 \mathrm{mM} \mathrm{Ru}(\text { bpy })_{2}$ (phendione $)^{2+}$. The imaging was then performed after the HOPG electrode was biased at a constant voltage for $30 \mathrm{~s}$ via a potentialstep program under the condition: initial potential $=0.4 \mathrm{~V}$; potential increment $=-0.1 \mathrm{~V} /$ step.

\section{Results and Discussion}

STM is a surface-sensitive technique that can resolve surface structures and alterations. Figure 1 shows in situ STM images of an HOPG electrode recorded before and after being modified with APBA and further with $\mathrm{Ru}(\mathrm{bpy})_{2}$ (phendione) ${ }^{2+}$.

The electrode increases in surface roughness $(r)$ from 0.259 (panel (a)) to $0.397 \mathrm{~nm}$ (panel (b)) after being treated with APBA, and further to $0.665 \mathrm{~nm}$ after being electrolyzed separately in $1 \mathrm{mM} \mathrm{Ru}(\mathrm{bpy})_{2}$ (phendione) $^{2+}$ at $-0.3 \mathrm{~V}$ constantly for $30 \mathrm{~s}$ (panel (c)). Here, the APBA treatment was carried out in a $0.1 \mathrm{M} \mathrm{HCl}$ solution containing $1 \mathrm{mM}$ APBA and an equimolar amount of $\mathrm{NaNO}_{2}$ via voltage cycling between 0 and $-0.6 \mathrm{~V}$ for one cycle at a scan rate of $50 \mathrm{mV} / \mathrm{s}$. The increments $(\Delta r), 0.13 \mathrm{~nm}$ and $0.27 \mathrm{~nm}$, suggest that the HOPG becomes covered with a submonolayer of APBA and $\mathrm{Ru}(\mathrm{bpy})_{2}$ (phendione) ${ }^{2+}$ and the reaction stoichiometry

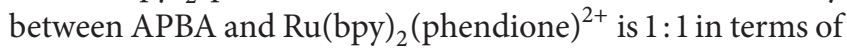




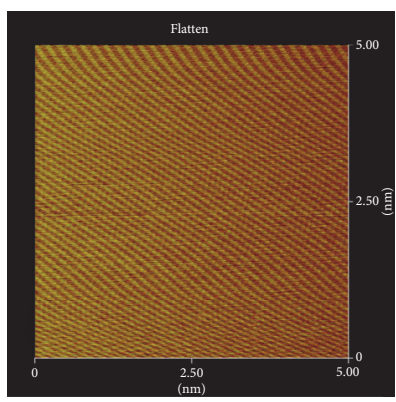

(a)

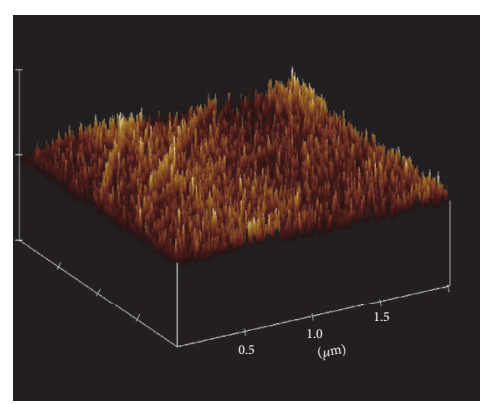

(b)

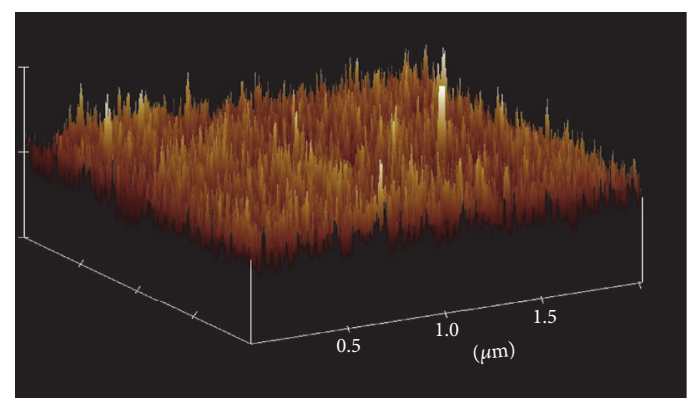

(c)

FIGURE 1: In situ STM images of an HOPG electrode recorded before (a) and after being treated with APBA (b) and further with $\mathrm{Ru}(\text { bpy })_{2}$ (phendione $)^{2+}$ (c).

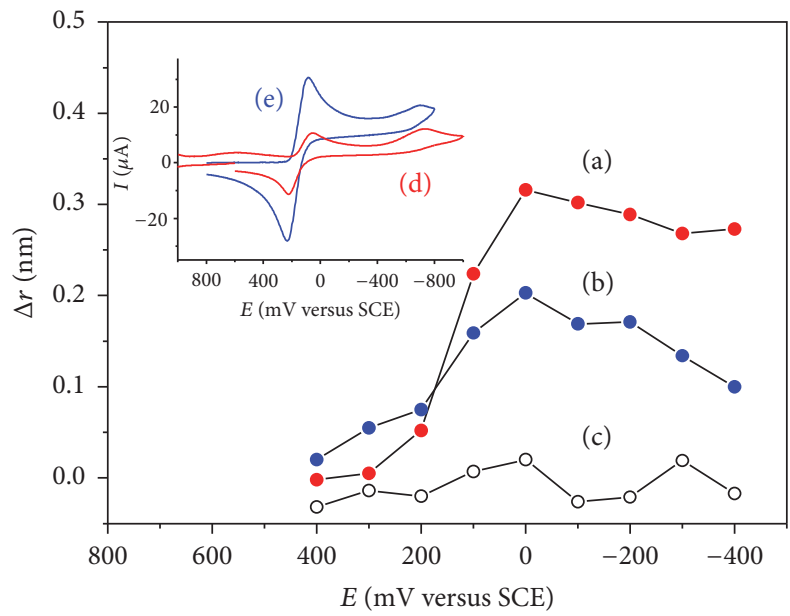

FIGURE 2: Relationships between $\Delta r$ and $E$ revealed from the APBAgrafted HOPG electrodes when reduced in the presence of $1 \mathrm{mM}$

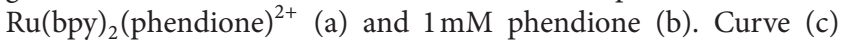
shows the results obtained in the absence of $\mathrm{Ru}(\mathrm{bpy})_{2}$ (phendione $)^{2+}$ or phendione. Inset shows the $\mathrm{CVs}$ of $1 \mathrm{mM} \mathrm{Ru}(\mathrm{bpy})_{2}$ (phendione $)^{2+}$ (d) and $1 \mathrm{mM}$ phendione (e).

molar ratio, estimated under the assumption that the molecular sizes of the compounds are approximately proportional to the cube roots of their cell volumes $\left(760 \AA^{3}\right.$ for APBA [15] and $5734 \AA^{3}$ for $\left.\mathrm{Ru}(\mathrm{bpy})_{2}(\text { phendione })^{2+}[16]\right)$. Surface scratching experiments support the STM results. The thickness of the APBA film is $0.25 \mathrm{~nm}$, and $0.38 \mathrm{~nm}$ for the ruthenium layer (Supplementary Material, Figure S3). The $\Delta r$ contributed by the second process, shown in Figure 2 (curve (a)), depends strongly on the applied voltage ( $E$, potential step), bearing a similarity to the cathodic wave of $\mathrm{Ru}(\mathrm{bpy})_{2}$ (phendione) $^{2+}$ (curve (d)) except for the plateau being more negative by $100 \mathrm{mV}$. Phendione showed similar responses to $E$ as

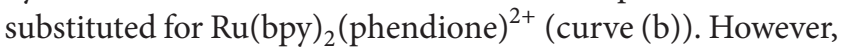
when $\mathrm{Ru}(\mathrm{bpy})_{2}$ (phendione $)^{2+}$ and phendione were excluded, the dependence became less significant (curve (c)). Omitting APBA results in trivial $\Delta r$ regardless of the presence of

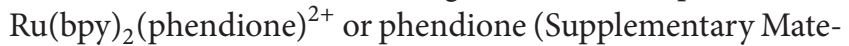
rial, Figure S4). The formation of a boronate ester features prominently in the second process, as proposed in Scheme 1. For the difference between the $\Delta r-E$ and $I-E$ curves in the plateau potential, the conversion of $\mathrm{Ru}(\mathrm{bpy})_{2}$ (phendione $)^{2+}$ to $\mathrm{Ru}(\mathrm{bpy})_{2}$ (phendiol $)^{2+}$ reaches completion only under the Cottrell condition, or at least $E-E_{\mathrm{pc}}<-100 \mathrm{mV}$ [17]. The difference is thus considered to be reasonable.

Electron exchange probing confirms the surface transformation. Selected results from EIS on $\mathrm{Fe}(\mathrm{CN})_{6}{ }^{3-/ 4-}$ at the HOPG electrodes are provided in Figure 3. The charge-transfer resistance $\left(R_{\mathrm{CT}}\right)$, resolved from the semicircles featured in the high frequency region inset in each panel, increases with increasing number of repetitions (No.) of the electrode being treated with APBA under conditions similar to those for the STM experiments but decreases with the number of times that the electrode is electrolyzed separately with $\mathrm{Ru}(\mathrm{bpy})_{2}$ (phendione) $)^{2+}$ at $-0.3 \mathrm{~V}(30 \mathrm{~s})$. The solution resistance $\left(R_{s}\right)$, the double-layer capacitance $\left(C_{\mathrm{dl}}\right)$, and the Warburg impedance $\left(Z_{W}\right)$ change as the modification proceeds as well, but in a minor way (Supplementary Material, Figure S5).

The cyclic voltammograms (CV) sampled in situ during the EIS measurements, shown in Figure 4, provide supplementary information concerning the $R_{\mathrm{CT}}$ alterations. The peak separation of the molecular probe $\left(\Delta E=E_{\mathrm{pa}}-E_{\mathrm{pc}}\right)$ varies as the modification proceeds, similar to the EIS $R_{\mathrm{CT}}$. Here, $E_{p a}$ and $E_{\mathrm{pc}}$ represent the peak potentials of the anodic and cathodic waves, respectively. In theory, electrode surface shrinkage only can result in current decreasing. The $\Delta E$ broadening and narrowing are obviously a result of kinetic perturbations, for which an altered surface charge is the likely cause. Based on the theory of Matsuda and Ayabe [17, 18], we extract the associated $R_{\mathrm{CT}}$ from the peak-to-half peak width, $\left|E_{\mathrm{pc} / 2}-E_{\mathrm{pc}}\right|$, of the cathodic waves inset in panel (a):

$$
\begin{aligned}
\left|E_{\mathrm{pc} / 2}-E_{\mathrm{pc}}\right| & =\left(\frac{R T}{n F}\right) \Delta(\Lambda, \alpha) \\
\Lambda & \approx \frac{(R T)^{3 / 2}}{\left\{(n F)^{5 / 2}(D v)^{1 / 2}\left(A c^{*} R_{\mathrm{CT}}\right)\right\}} .
\end{aligned}
$$

Here, $\Delta(\Lambda, \alpha)$ is an implicit function of the electron-transfer coefficient $\alpha$ and the dimensionless parameter $\Lambda$, a function of the electron-transfer number $(n)$, the surface area of the 


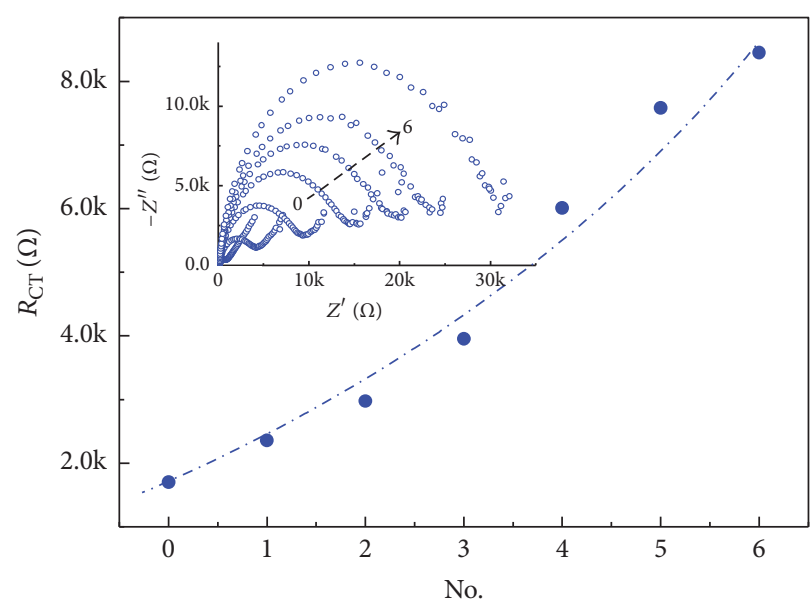

(a)

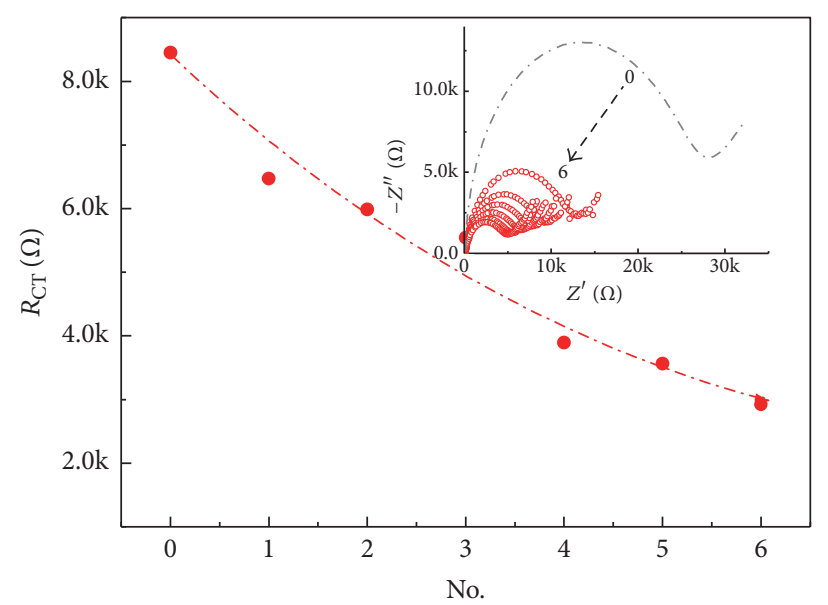

(b)

Figure 3: Correlations of the $R_{\mathrm{CT}}$ resolved from the Nyquist plots inset in each panel for $1 \mathrm{mM}$ of $\mathrm{Fe}(\mathrm{CN})_{6}{ }^{3-/ 4-}$ on $\mathrm{HOPG}$ with the number of repetitions (No.) of the electrode being treated with $1 \mathrm{mM}$ APBA (a) and further with $1 \mathrm{mM}$ of Ru(bpy) ${ }_{2}(\text { phendione })^{2+}(\mathrm{b})$.

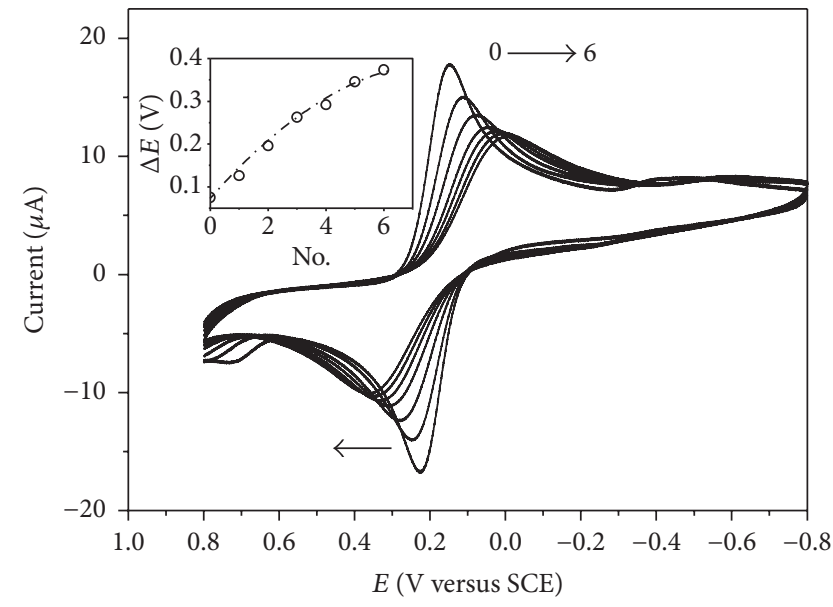

(a)

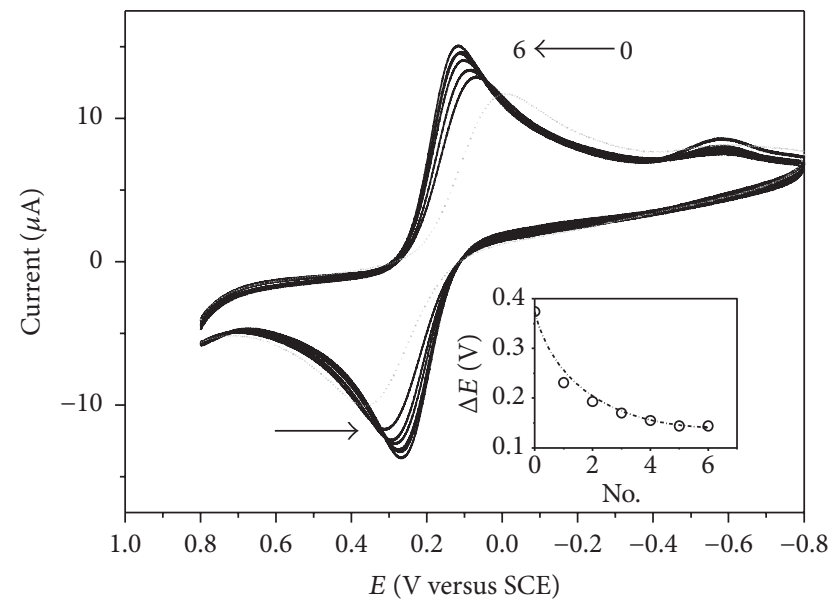

(b)

FIGURE 4: In situ CVs recorded during the EIS measurements as in Figure 3. Insets show that the values of the peak separation $(\Delta E)$ are functions of the number of the electrode being treated with $1 \mathrm{mM} \mathrm{APBA}(\mathrm{a})$ and further with $1 \mathrm{mM}$ of $\mathrm{Ru}(\mathrm{bpy})_{2}(\mathrm{phendione})^{2+}(\mathrm{b})$.

electrode $(A)$, the diffusion coefficients of $\mathrm{Fe}(\mathrm{CN})_{6}{ }^{3-/ 4-}(D$, presumed $\left.1 \times 10^{-5} \mathrm{~cm}^{2} / \mathrm{s}\right)$, the initial concentration of the probe $\left(c^{*}, 1 \times 10^{-6} \mathrm{~mol} / \mathrm{cm}^{3}\right)$, and the scan rate $(v, 0.05 \mathrm{~V} / \mathrm{s})$.

The results obtained under $\alpha: 0.3,0.4$, and 0.5 are shown in Figure 5 and plotted against the EIS counterparts for comparison. Despite the fact that the number of the data points is limited, it can be seen that $R_{\mathrm{CT}}(\mathrm{CV}) \approx R_{\mathrm{CT}}(\mathrm{EIS})$ as $\alpha=0.3$. The $\alpha$ found in this case shows consistency with those reported in the literature $(0.23 \pm 0.03)$ [19], confirming that APBA and the ruthenium complex have been grafted on HOPG electrodes as proposed.

The surface assembly is also duplicated on CNTs under conditions similar to those for the HOPG with a slight modification using sacrificial electron donors as a substitute for the electrochemical means. Three representative AFM images of a selected CNT recorded before and after each modification process are presented in Figure 6. APBA forms nanoparticles on the CNT (panel (b), denoted by APBA|CNT), and $\mathrm{Ru}(\mathrm{bpy})_{2}$ (phendione $)^{2+}$ contributes an additional thickness to the tube (panel (c), denoted by Ru|APBA|CNT). The thickness ratio of the grafted APBA to the $\mathrm{Ru}(\mathrm{bpy})_{2}$ (phendione $)^{2+}$ layer is roughly $1: 2$ according to the surfaces of spots (A), (B), $(\mathrm{C})$, and $(\mathrm{D})$ that were exposed via electron beam ablation. The ratio is consistent with the HOPG results, despite the adsorbates being less uniformly distributed than expected. We attempted to estimate the molar ratio of ruthenium to boron on the Ru|APBA|CNT tubes using XPS, but the attempts were unsuccessful, due to the facts that the $B$ signals $(1 \mathrm{~s}, 187 \mathrm{eV})$ are weak and carbon $(1 \mathrm{~s}, 284 \mathrm{eV})$ severely interferes with the Ru signals (3d, $280 \mathrm{eV}$ ). Nevertheless, the modifications are supported by Raman spectroscopy. As shown in Figure 7, the adsorption of APBA perturbs the Raman spectra 


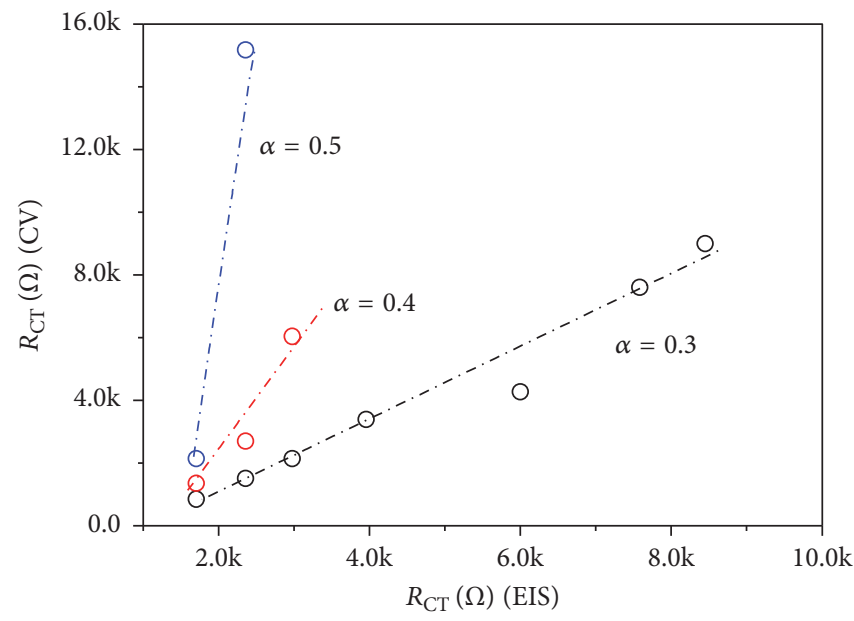

FIGURE 5: Correlations between the $R_{\mathrm{CT}}$ resolved from EIS and CV.

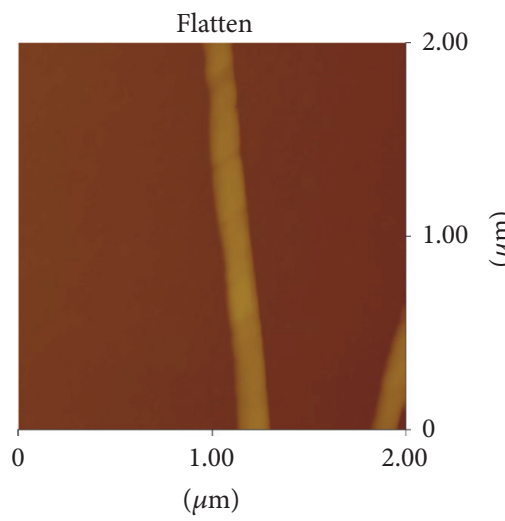

(a) Bare CNT

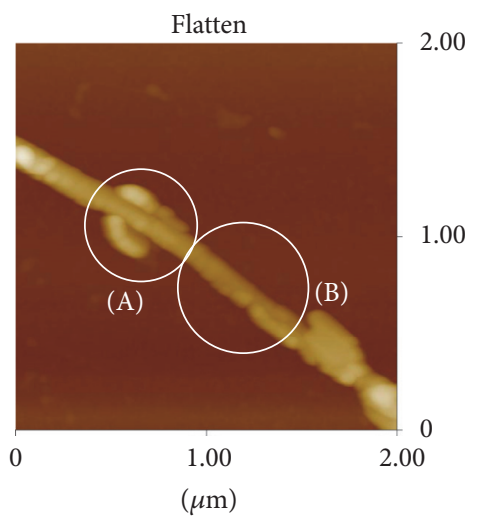

(b) $\mathrm{ABPA} \mid \mathrm{CNT}$

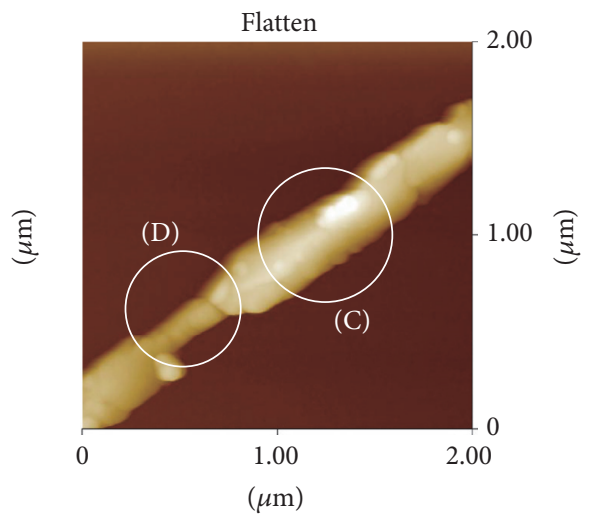

(c) $\mathrm{Ru}|\mathrm{APBA}| \mathrm{CNT}$

Figure 6: AFM images of bare CNT, ABPA|CNT, and Ru|APBA|CNT.

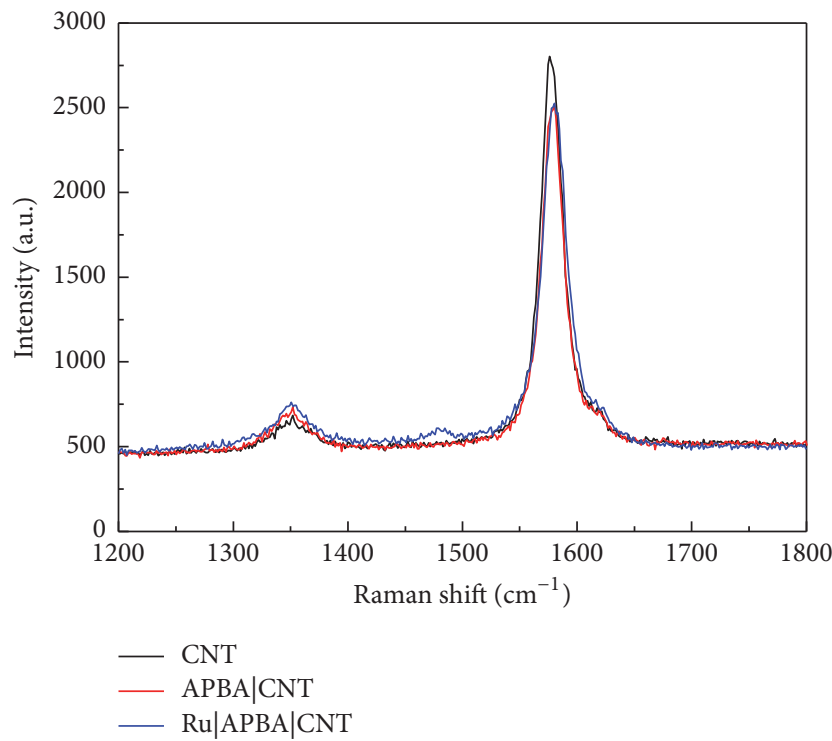

FIGURE 7: Raman spectra of CNTs before and after being modified

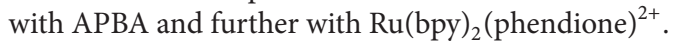

of the host, in which the D band $\left(1340 \mathrm{~cm}^{-1}\right)$ is enhanced at the expense of the $\mathrm{G}$ band $\left(1576 \mathrm{~cm}^{-1}\right)$, similar to the reports of CNTs that are produced during their functionalization with aromatic diazonium salts [20]. These results indicate that the hybridization of some of the carbon atoms on the surface of the host have changed from $\mathrm{sp}^{2}$ to $\mathrm{sp}^{3}$ due to the coupling of the APBA radical [21]. Noticeably, the subsequent modification with $\mathrm{Ru}(\mathrm{bpy})_{2}$ (phendione) ${ }^{2+}$ appear not to further perturb the $\mathrm{D}$ band or the $\mathrm{G}$ band. We consider this an indication that the ruthenium compound is mainly adsorbed on the preadsorbed APBA instead of the host, which supports the mechanism proposed in Scheme 1. The Ru|APBA|CNT tube exhibits photomagnetism towards external magnets at room temperature as floating on water, similar to the tubes modified with $\mathrm{Ru}(\mathrm{bpy})_{2}$ (phen- $\left.\mathrm{NH}_{2}\right)^{2+}$ [5]. The average mobility measured for the photo-illuminated Ru|APBA|CNTs $\left(\lambda_{\text {ex }}\right.$ : $473 \mathrm{~nm} ; 27 \mathrm{~mW}$ ) on water was $0.3 \mathrm{~mm} / \mathrm{min}$ (65 Gauss). The bare CNTs remained unmoved under similar conditions.

The CNT tubes shown in Figure 6 were also investigated for their magnetic properties by the magnetic-mode AFM (MFM) [5, 22]. As shown in Figure 8, the oscillation of the 


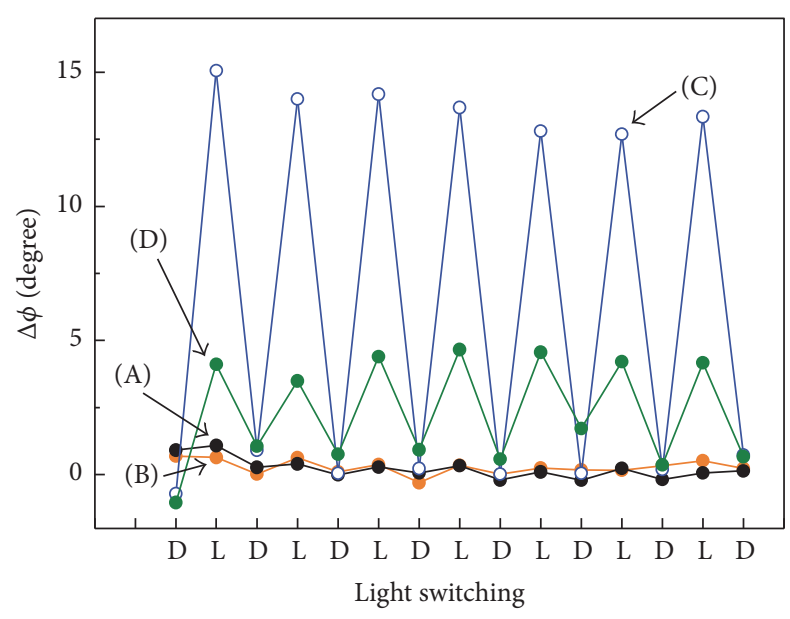

FIgURE 8: Changes in $\Delta \phi$ of an MFM tip set $4 \mathrm{~nm}$ above spots (A), (B), (C), and (D) as in Figure 6 under chopped light conditions.

MFM tip changes negligibly (curves (A) and (B)) as the tip is set $4 \mathrm{~nm}$ atop APBA|CNT at spots (A) and (B), regardless of lights $(\lambda: 473 \mathrm{~nm}, 26 \mathrm{~mW})$ on (L) and off (D). In contrast, greater changes are observed under similar chopped light conditions as the tip is switched to the Ru|APBA|CNT at spot (C) (curve (C)). The contrast indicates that the ruthenium adsorbate has the ability to convert photo energy into magnetism. Here, $\Delta \phi$ represents the shift in the cantilever's phase $(\phi)$ of oscillation relative to the piezo drive caused by the magnetic force of the samples recorded at a constant lift height $(4 \mathrm{~nm})$. The $\Delta \phi$ recorded in curve (C) shows no signs of deterioration, suggesting that the chemical linkages between the grafted APBA and the carbon substrate and the ruthenium precursor are stable. Regarding the origin of the photomagnetism, research has reported that $\mathrm{Ru}(\mathrm{bpy})_{2}$ (phendione) $\cdot 2 \mathrm{PF}_{6}$ can be paramagnetic at a temperature higher than $293 \mathrm{~K}$ [23]. The paramagnetic characteristic arises due to mixing of the MLCT excited state with an open shell triplet state on the phendione moiety driven by aromatization. Facilitated by admixture of singlet character from the MLCT state, the stabilized open shell phendione structure can be thermally populated from the ground state of the complex. Accordingly, we ascribe the photomagnetism to the MLCT state of the ruthenium adsorbate. Here, we notice that the dark $\Delta \phi$ of the Ru|APBA|CNT is not compatible with the light counterpart. The photomagnetism is confirmed to originate from the photoinduced MLCT, rather than the thermal-populated excited state. It should be noted that spot $\mathrm{d}$ also shows photomagnetism, even though its surface has been ablated. We attribute the unexpected photomagnetism to a stray magnetic field induced by the $\mathrm{Ru}(\mathrm{bpy})_{2}{\text { (phendiol })^{2+}}^{2+}$ adsorbed on the neighboring APBA film or from the ablated debris, because the effective diameter of the apex of the MFM tip is $\sim 0.2 \mu \mathrm{m}$, close to the lateral distance of region (D) $(\sim 0.2 \mu \mathrm{m})$. Nevertheless, the unexpected photomagnetism can be taken as an additional support for the conclusion that

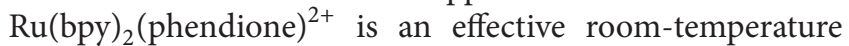
photomagnetism precursor and APBA is a useful molecular adhesive for $\mathrm{Ru}(\mathrm{bpy})_{2}$ (phendione $)^{2+}$ to carbon substrates.

\section{Conclusions}

3-Aminophenylboronic acid (APBA) and $\mathrm{Ru}(\mathrm{bpy})_{2}$ (phendione $)^{2+}$ are useful precursors for fabricating photosensitive carbon surfaces. APBA forms nanoscale films on HOPG and CNTs as reduced in acidic $\mathrm{NaNO}_{2}$ solutions chemically or electrochemically. The grafted boronic acid can adhere $\mathrm{Ru}(\mathrm{bpy})_{2}$ (phendione $)^{2+}$ to the carbon substrates by forming $1: 1$ ester adduct with the phendione ligand after it is reduced to the corresponding alcohol. The resulting composites show photomagnetism at room temperature when exposed to irradiation from a $473 \mathrm{~nm}$ light. The magnetism shows no signs of deterioration. We conclude that $\mathrm{Ru}(\mathrm{bpy})_{2}$ (phendione) $)^{2+}$ and APBA are redox-controllable building blocks that are useful for preparing photomagnetic carbon surfaces.

\section{Competing Interests}

The authors declare that they have no competing interests.

\section{Acknowledgments}

The authors wish to acknowledge Professor Cheng-Huang Lin for providing the light sources. This work is supported by the National Science Council, Republic of China (Grants nos. NSC 102-2113-M-003-002-MY3 and MOST 105-2119-M003-006).

\section{References}

[1] A. Bergen, S. Rudiuk, M. Morel, T. Le Saux, H. Ihmels, and D. Baigl, "Photodependent melting of unmodified dna using a photosensitive intercalator: a new and generic tool for photoreversible assembly of DNA nanostructures at constant temperature," Nano Letters, vol. 16, no. 1, pp. 773-780, 2016.

[2] S. Kundu and A. Patra, "Nanoscale strategies for light harvesting," Chemical Reviews, vol. 117, no. 2, pp. 712-757, 2017.

[3] M. Husham and Z. Hassan, "Synthesis of nanocrystalline CdS thin films via microwave-assisted chemical bath deposition for highly photosensitive and rapid response photodetectors," Journal of Nanoelectronics and Optoelectronics, vol. 10, no. 6, pp. 783789, 2015.

[4] P. C. Mondal, P. Roy, D. Kim, E. E. Fullerton, H. Cohen, and R. Naaman, "Photospintronics: magnetic field-controlled photoemission and light-controlled spin transport in hybrid chiral oligopeptide-nanoparticle structures," Nano Letters, vol. 16, no. 4, pp. 2806-2811, 2016.

[5] W. S. Lin, Y.-H. Han, T.-Y. Chang, C. M. Wang, C.-H. Chang, and J.-S. Tsay, "Photomagnetic carbon nanotubes at ambient conditions," Journal of Physical Chemistry C, vol. 119, no. 35, pp. 20673-20680, 2015.

[6] C. M. Wang, S.-Y. Chung, H.-J. Jao, and W.-H. Hung, "ALOpatternable artificial flavin: phenazine, phenothiazine, and phenoxazine," Journal of Physical Chemistry C, vol. 115, pp. 19781984, 2011.

[7] D. G. Hall, Boronic Acids, Wiley-VCH, New York, NY, USA, 2005.

[8] N. Plesu, A. Kellenberger, I. Taranu, B. O. Taranu, and I. Popa, "Impedimetric detection of dopamine on poly(3-aminophenylboronic acid) modified skeleton nickel electrodes," Reactive and Functional Polymers, vol. 73, no. 5, pp. 772-778, 2013. 
[9] K. Lacina, P. Skládal, and T. D. James, "Boronic acids for sensing and other applications-a mini-review of papers published in 2013," Chemistry Central Journal, vol. 8, no. 1, article no. 60, 2014.

[10] C.-C. Wang, J. W. Hennek, A. Ainla et al., "A paper-based 'pop-up' electrochemical device for analysis of beta-hydroxybutyrate," Analytical Chemistry, vol. 88, no. 12, pp. 6326-6333, 2016.

[11] F. Calderazzo, G. Pampaloni, and V. Passarelli, "1,10-Phenanthroline-5,6-dione as a building block for the synthesis of homo- and heterometallic complexes," Inorganica Chimica Acta, vol. 330, no. 1, pp. 136-142, 2002.

[12] C. A. Goss and H. D. Abruña, "Spectral, electrochemical and electrocatalytic properties of 1,10-phenanthroline-5,6dione complexes of transition metals," Inorganic Chemistry, vol. 24, no. 25, pp. 4263-4267, 1985.

[13] V. Goudy, J. Maynadié, X. L. Goff, D. Meyer, and M. Fontecave, "Synthesis, electrochemical and spectroscopic properties of ruthenium(II) complexes containing 2,6-di(1H-imidazo[4,5f][1,10]phenanthrolin-2-yl)aryl ligands," New Journal of Chemistry, vol. 40, no. 2, pp. 1704-1714, 2016.

[14] M. Wu, X. Mao, X. Li, X. Yang, and L. Zhu, "1,10-phenanthroline-5,6-dione adsorbed on carbon nanotubes: the electrochemistry and catalytic oxidation of ascorbic acid," Journal of Electroanalytical Chemistry, vol. 682, pp. 1-6, 2012.

[15] A. Vega, M. Zarate, H. Tlahuext, and H. Höpfl, "3-aminophenylboronic acid monohydrate," Acta Crystallographica Section E: Crystallographic Communications, vol. 66, no. 6, Article ID o1260, 2010.

[16] J. A. Rusanova, S. Decurtins, E. B. Rusanov, and H. Stoeckli-Evans, "Crystal structure of bis(2,2'-bipyridine-N,N')-[1,10phenanthroline-5,6-dione]ruthenium(II) dihexafluorophosphate acetone solvate, $\left[\mathrm{Ru}\left(\mathrm{C}_{10} \mathrm{H}_{8} \mathrm{~N}_{2}\right)_{2}\left(\mathrm{C}_{12} \mathrm{H}_{6} \mathrm{~N}_{2} \mathrm{O}_{2}\right)\right][\mathrm{PF} 6] 2$. $1.75\left(\mathrm{CH}_{3}\right)_{2} \mathrm{CO}$," Zeitschrift für Kristallographie-New Crystal Structures, vol. 217, pp. 571-574, 2002.

[17] A. J. Bard and L. R. Faulkner, Eds., Electrochemical Methods: Fundamentals and Applications, chapter 6, John Wiley \& Sons, New York, NY, USA, 1980.

[18] H. Matsuda and H. Z. Ayabe, "Zur theorie der RandlesSevčikschen kathodenstrahl-polarographie, zeitschrift für elektrochemie," Elektrochemie, vol. 59, pp. 494-503, 1955.

[19] W. J. Blaedel and R. C. Engstrom, "Investigations of the ferricyanide-ferrocyanide system by pulsed rotation voltammetry," Analytical Chemistry, vol. 50, no. 3, pp. 476-479, 1978.

[20] K. Balasubramanian, M. Friedrich, C. Jiang et al., "Electrical transport and confocal Raman studies of electrochemically modified individual carbon nanotubes," Advanced Materials, vol. 15, no. 18, pp. 1515-1518, 2003.

[21] J. Maultzsch, S. Reich, C. Thomsen et al., "Raman characterization of boron-doped multiwalled carbon nanotubes," Applied Physics Letters, vol. 81, no. 14, pp. 2647-2649, 2002.

[22] R. D. Gomez, A. O. Pak, A. J. Anderson, E. R. Burke, A. J. Leyendecker, and I. D. Mayergoyz, "Quantification of magnetic force microscopy images using combined electrostatic and magnetostatic imaging," Journal of Applied Physics, vol. 83, no. 11, pp. 6226-6228, 1998.

[23] R. D. Schmidt, C. A. Kent, J. J. Concepcion, W. Lin, T. J. Meyer, and M. D. E. Forbes, "A little spin on the side: solvent and temperature dependent paramagnetism in [RuII(bpy)2(phendione)]2+," Dalton Transactions, vol. 43, no. 47, pp. 17729-17739, 2014. 

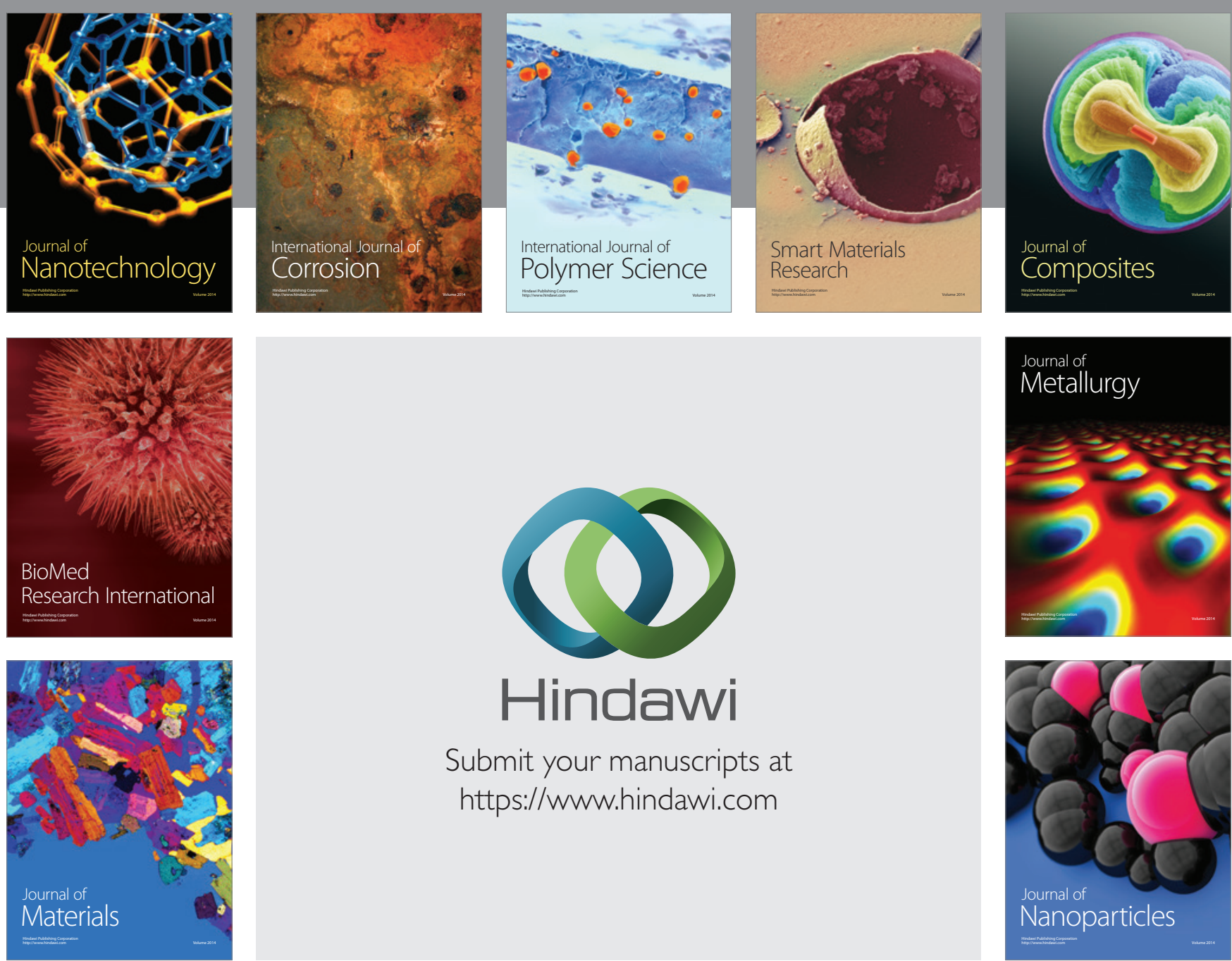

\section{Hindawi}

Submit your manuscripts at

https://www.hindawi.com

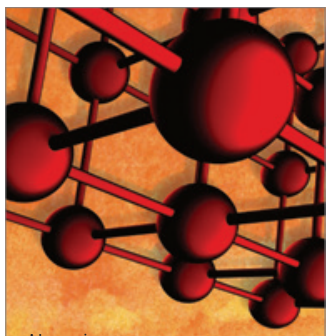

Materials Science and Engineering
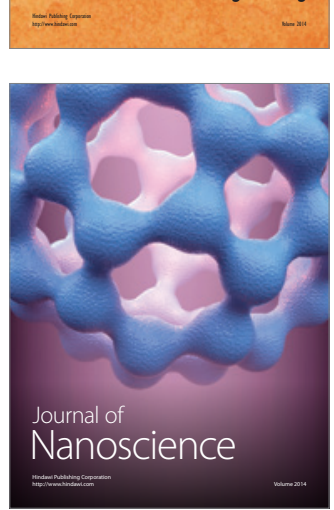
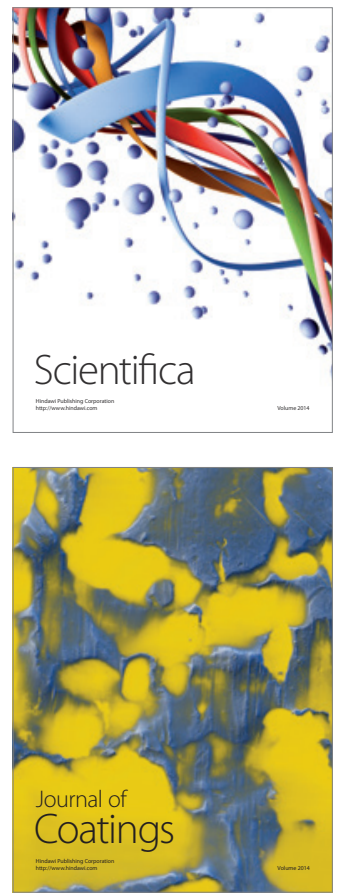
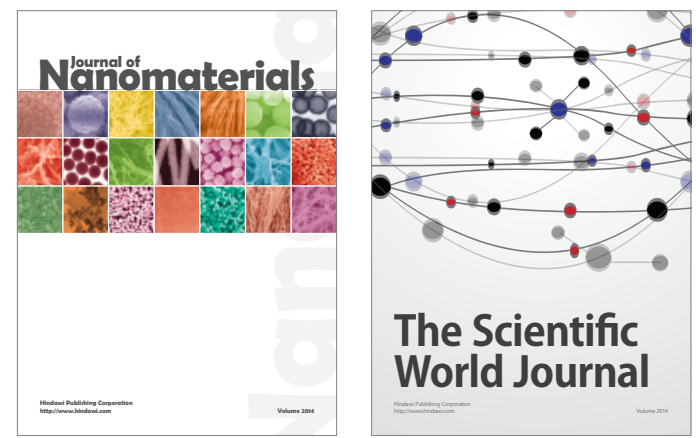

The Scientific World Journal
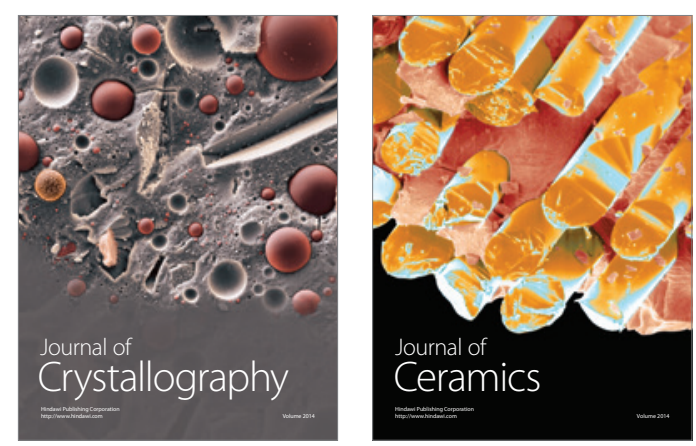
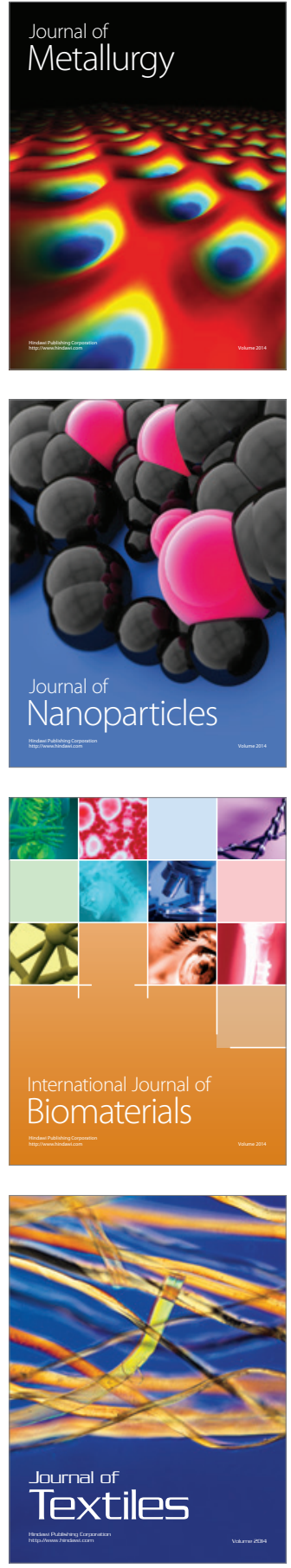